\title{
Rola Rady Ministrów w wykonywaniu orzeczeń Europejskiego Trybunatu Praw Człowieka
}

\author{
Anna Chmielarz-Grochal \\ Uniwersytet Łódzki, Wydział Prawa i Administracji \\ Katedra Prawa Konstytucyjnego
}

\section{Uwagi ogólne}

W styczniu 2018 r. minęło 25 lat obowiązywania w Polsce Konwencji o ochronie praw człowieka i podstawowych wolności, sporządzonej w Rzymie dnia 4 listopada 1950 r. ${ }^{1}$ (dalej: Konwencja lub EKPC). Konwencja - zgodnie z art. 87 i art. 91 w zw. z art. 9 Konstytucji - jest częścią porządku prawnego Rzeczypospolitej Polskiej, źródłem prawa powszechnie obowiązującego, podlega bezpośredniemu stosowaniu i ma pierwszeństwo w razie kolizji z ustawami. Relacje między Konwencją a Konstytucją Rzeczypospolitej Polskiej zasadniczo opierają się na równoważności standardów ochrony wolności i praw. Z obydwu wymienionych aktów wynikają dla państwa określone obowiązki, zarówno o charakterze pozytywnym, jak i negatywnym ${ }^{2}$. Przestrzeganie standardów konwencyjnych mieści się także w ramach wynikającego z art. 9 Konstytucji obowiązku przestrzegania przez Rzeczpospolitą Polską wiążącego ją prawa międzynarodowego.

W praktyce obowiązywania i stosowania Konwencji szczególne znaczenie ma fakt, że od 1 maja 1993 r. Polska podlega również jurysdykcji Europejskiego Trybunału Praw Człowieka w Strasburgu (dalej: Trybunał lub ETPC) w sprawach skarg indywidualnych. Ma to dwojakiego rodzaju konsekwencje.

Po pierwsze, obywatele polscy mogą skorzystać z przewidzianej Konwencją możliwości wniesienia przez każdą osobę, organizację pozarządową lub grupę jednostek skargi opartej na zarzucie naruszenia przez państwo praw zawartych w Konwencji

1 Dz.U. z 1993 r., nr 61, poz. 284 ze zm.

2 Por. L. Garlicki, Obowiq̨zywanie Europejskiej Konwencji Praw Człowieka w porządku prawnym Rzeczypospolitej Polskiej, „Biuletyn Biura Informacji Rady Europy” 2003, nr 3, s. 21; L. Garlicki, M. Masternak-Kubiak, Władza sq̨downicza RP a stosowanie prawa międzynarodowego i prawa Unii Europejskiej, [w:] K. Wójtowicz (red.), Otwarcie Konstytucji RP na prawo międzynarodowe i procesy integracyjne, Warszawa 2006, s. 179. 
lub jej protokołach, ale dopiero po wyczerpaniu wszystkich środków odwoławczych przewidzianych prawem wewnętrznym, zgodnie z powszechnie uznanymi zasadami prawa międzynarodowego, $\mathrm{w}$ ciągu sześciu miesięcy od daty podjęcia ostatecznej decyzji (art. 34 i 35 EKPC). Z mocy Konwencji państwo obowiązane jest wydany w tym trybie wyrok ETPC wykonać. Ciężar tego obowiązku spoczywa z reguły na organach władzy wykonawczej danego państwa. W Polsce podmiotem odpowiedzialnym za wykonywanie orzeczeń ETPC oraz wdrażanie i upowszechnianie standardów konwencyjnych jest Rada Ministrów. Trzeba przy tym zaznaczyć, że wyroki Trybunału nie mają charakteru konstytutywnego, tylko deklaratoryjny. Wykonanie wyroków ETPC przez państwo polega na realizacji określonych w nich środków indywidualnych (tj. wypłaty zasądzonej kwoty oraz usunięciu stanu naruszenia czy też tzw. restitutio in integrum) ${ }^{3}$ lub generalnych (zmiany prawa lub praktyki jego stosowania w danej dziedzinie) $)^{4}$. Wykonywanie wyroków Trybunału pozostaje pod nadzorem Komitetu Ministrów Rady Europy (art. 46 EKPC).

Po drugie, wypracowane i rozwijane w orzecznictwie ETPC konwencyjne standardy ochrony praw człowieka, jako część acquis conventionnel, powinny być przez państwa - strony Konwencji uwzględniane zarówno w działalności organów prawodawczych, jak i organów stosujących prawo, zwłaszcza sądów ${ }^{6}$. Wykładnia EKPC dokonywana przez Trybunał pozwala zidentyfikować i właściwie zinterpretować konwencyjne standardy ochrony praw jednostki, a w ten sposób dostarcza organom krajowym wskazówek interpretacyjnych co do sposobu i kierunku rozumienia przepisów stosowanych w sprawach dotyczących sfery wolności oraz praw jednostki.

3 Są to środki mające na celu zapewnienie, by stwierdzony przez Trybunał stan naruszenia EKPC wobec skarżącego ustał, a także by skarżący został postawiony, na ile to możliwe, w tej samej sytuacji, z której korzystał przed naruszeniem Konwencji.

4 Są to środki mające na celu zakończenie stanu naruszenia Konwencji i zapobieżenie nowym, podobnym naruszeniom tego aktu na przyszłość.

5 Zob. Rules of the Committee of Ministers for the supervision of the execution of judgments and of the terms of friendly settlements (adopted by the Committee of Ministers on 10 May 2006 at the $964^{\text {th }}$ meeting of the Ministers' Deputies and amended on 18 January 2017 at the $1275^{\text {th }}$ meeting of the Ministers' Deputies), https://search.coe.int/cm/Pages/result_details. aspx?Objectld=09000016806dd2a5 (dostęp: 15.09.2018).

6 Zob. H. Keller, A. Stone Sweet, The Reception of the ECHR in National Legal Orders, [w:] H. Keller, A. Stone Sweet (red.), A Europe of Rights. The Impact of the ECHR on National Legal Systems, Oxford 2008, s. 3 i n.; zob. też: E. Bjorge, Domestic Application of the ECHR: Courts as Faithful Trustees, Oxford 2015, s. 1; L. Garlicki, Modelowy sposób stosowania Konwencji Europejskiej i orzecznictwa strasburskiego przez sądy, [w:] IX Seminarium Warszawskie. Dysfunkcje polskiego prawa - jak poprawić system środków prawnych w Polsce?, Warszawa 2016, s. 24 i n.; L. Garlicki, Rola sędziego krajowego w procesie wykonywania orzeczeń Europejskiego Trybunału Praw Człowieka, [w:] IX Seminarium Warszawskie..., s. 36 i n.; N. Półtorak, Rola sądów administracyjnych w przestrzeganiu Konwencji o ochronie praw człowieka i podstawowych wolności, [w:] IX Seminarium Warszawskie..., s. 158 i n.; A. Chmielarz-Grochal, P. Florjanowicz-Błachut, Bezpośrednie stosowanie Konwencji o ochronie praw człowieka i podstawowych wolności przez sq̨dy administracyjne, [w:] E. Wójcicka (red.), Sqqdowa kontrola administracji publicznej. Doświadczenia. Dylematy. Perspektywy, Częstochowa 2017, s. 341-369. 
Komitet Ministrów Rady Europy wydał dotychczas również wiele zaleceń dotyczących poszanowania praw człowieka, w których wskazuje państwom podlegającym jurysdykcji ETPC środki i kierunki pożądanych działań, zarówno w kontekście podejmowania środków skutkujących szybkim i skutecznym wykonaniem orzeczenia Trybunału ${ }^{7} \mathrm{i}$ uruchamiania procedur $\mathrm{w}$ sprawie ponownego rozpatrywania lub wznawiania pewnych spraw na poziomie krajowym na skutek wyroku Trybunału ${ }^{8}$, jak i upowszechniania standardów wynikających z tej umowy międzynarodowej i orzecznictwa $\mathrm{ETPC}^{9}$ oraz zapobiegania naruszeniom Konwencji na przyszłość ${ }^{10}$. Nie bez znaczenia dla zapewnienia efektywności ochrony praw człowieka są również Deklaracje Konferencji Wysokiego Szczebla na temat przyszłości Europejskiego Trybunału Praw Człowieka z Interlaken (2010), Izmiru (2011) i Brighton (2012) oraz Deklaracja Konferencji Wysokiego Szczebla w Brukseli na temat implementacji Konwencji o ochronie praw człowieka i podstawowych wolności - naszej wspólnej odpowiedzialności (2015) i Deklaracja Konferencji Wysokiego Szczebla w Kopenhadze na temat dalszej reformy systemu Europejskiej Konwencji Praw Człowieka $(2018)^{11}$.

Przedmiotem niniejszego opracowania jest rola Rady Ministrów w wykonywaniu orzeczeń ETPC, odczytywana przez pryzmat realizowanych w tym celu zadań i podejmowanych działań faktycznych. Wyodrębnione części tekstu oraz zawarte w nich uwagi służą potwierdzeniu tezy o wiodącej roli Rady Ministrów w wykonywaniu wyroków Trybunału' ${ }^{12}$.

7 Zalecenie CM/Rec(2008)2 Komitetu Ministrów dla państw członkowskich dotyczące skutecznej zdolności krajowej do szybkiego wykonywania wyroków Europejskiego Trybunału Praw Człowieka, https://msz.gov.pl/pl/polityka_zagraniczna/europejski_trybunal_praw_czlowieka/zalecenia_km (dostęp: 15.09.2018).

8 Zalecenie $\operatorname{Rec}(2000) 2$ Komitetu Ministrów dla państw członkowskich w sprawie ponownego rozpatrywania lub wznawiania pewnych spraw na poziomie krajowym na skutek wyroku Europejskiego Trybunału Praw Człowieka, https://msz.gov.pl/pl/polityka_zagraniczna/europejski_trybunal_praw_czlowieka/zalecenia_km (dostęp: 15.09.2018).

9 Zalecenie $\operatorname{Rec}(2002) 13$ Komitetu Ministrów dla państw członkowskich w sprawie publikacji i rozpowszechniania w państwach członkowskich tekstu Europejskiej Konwencji Praw Człowieka oraz orzecznictwa Europejskiego Trybunału Praw Człowieka, https://msz.gov.pl/pl/polityka_zagraniczna/europejski_trybunal_praw_czlowieka/zalecenia_km (dostęp: 15.09.2018).

10 Zalecenie Rec(2004)5 Komitetu Ministrów dla państw członkowskich w sprawie kontroli zgodności projektów aktów prawnych oraz istniejącego prawa i praktyki administracyjnej ze standardami wyrażonymi w Europejskiej Konwencji Praw Człowieka; Zalecenie Rec(2004)6 Komitetu Ministrów dla państw członkowskich w sprawie ulepszenia krajowych środków prawnych (odwoławczych); Zalecenie CM/Rec(2010)3 Komitetu Ministrów dla państw członkowskich dotyczące skutecznych środków odwoławczych na przewlekłość postępowania, wraz z Podręcznikiem dobrych praktyk; https://msz.gov.pl/pl/polityka_zagraniczna/europejski_trybunal_praw_czlowieka/zalecenia_km (dostęp: 15.09.2018).

11 Zob. https://msz.gov.pl/pl/polityka_zagraniczna/europejski_trybunal_praw_czlowieka/zalecenia_km (dostęp: 15.09.2018).

12 Zob. też: W. Brodziński, Rozdział 11: Rada Ministrów, [w:] D. Górecki (red.), Polskie prawo konstytucyjne, Warszawa 2015, s. 207. 


\section{Podstawy prawne kompetencji Rady Ministrów do działania w celu wykonania orzeczeń Europejskiego Trybunału Praw Człowieka}

Konwencja nie określa ani rodzajów organów krajowych, które powinny wykonywać orzeczenia ETPC, ani rodzaju czy form takich działań. Pozostaje to w sferze regulacji prawa krajowego o charakterze ustrojowym. Wynikający z art. 46 ust. 1 EKPC obowiązek państw do przestrzegania ostatecznego wyroku Trybunału we wszystkich sprawach, w których są stronami, dotyczy - jak można sądzić - w głównej mierze sfery działania władzy wykonawczej. Trzeba jednak mieć na względzie, że wynikający z art. 9 Konstytucji obowiązek przestrzegania prawa międzynarodowego jest adresowany do wszystkich organów państwa. Podstawy kompetencji Rady Ministrów w tym zakresie określa Konstytucja, choć nie czyni tego wprost, tj. przez bezpośrednie powierzenie rządowi kompetencji do wykonywania orzeczeń Trybunału.

Wykonywanie orzeczeń ETPC mieści się w ramach kompetencji Rady Ministrów z zakresu prowadzenia polityki zagranicznej (art. 146 ust. 1-2 i ust. 4 pkt 9 Konstytucji). Mimo że kompetencja do prowadzenia polityki zagranicznej jest konstytucyjnie rozdzielona między Radę Ministrów, Prezydenta Rzeczypospolitej Polskiej oraz Sejm i Senat, to jednak tylko w odniesieniu do rządu ustawodawca konstytucyjny posłużył się formułą „prowadzi politykę [...] zagraniczną" (art. 146 ust. 1$)^{13}$. Ponadto, zgodnie z Konstytucją Rada Ministrów „sprawuje ogólne kierownictwo $\mathrm{w}$ dziedzinie stosunków $\mathrm{z}$ innymi państwami i organizacjami międzynarodowymi” (art. 146 ust. 4 pkt 9) ${ }^{14}$. Tym samym nie ma wątpliwości, że Rada Ministrów jest najbardziej konstytucyjnie umocowana do podejmowania decyzji związanych $\mathrm{z}$ wypełnianiem zobowiązań prawnomiędzynarodowych wynikających z członkostwa Polski w Radzie Europy, a więc także z podlegania jurysdykcji ETPC. Nie oznacza to, że pozostałe organy nie są odpowiedzialne za wykonywanie orzeczeń Trybunału, zwłaszcza w zakresie podejmowanych tzw. środków generalnych, polegających w szczególności na dokonywaniu niezbędnych zmian legislacyjnych, zmianie praktyki organów krajowych czy tłumaczeniu, publikacji i upowszechnianiu orzeczeń ${ }^{15}$.

13 Zob. L. Mażewski, Prowadzenie polityki zagranicznej w Rzeczypospolitej Polskiej, „Ruch Prawniczy, Ekonomiczny i Socjologiczny" 2009, nr 3, s. 9.

14 Zob. D. Dudek, Komentarz do art. 146, [w:] M. Safjan, L. Bosek (red.), Konstytucja RP, t. II: Komentarz. Art. 87-243, Warszawa 2016, s. 760 i n.

15 Zob. R. Kropiwnicki, System wykonywania wyroków Europejskiego Trybunału Praw Człowieka w Polsce, [w:] M. Jabłoński, S. Jarosz-Żukowska (red.), Aktualne wyzwania ochrony wolności i praw jednostki. Prace uczniów i wspótpracowników dedykowane Profesorowi Bogusławowi Banaszakowi, Wrocław 2014, s. 301 i n. 
Powierzone Radzie Ministrów w art. 146 ust. 4 pkt 9 Konstytucji tzw. ogólne kierownictwo w dziedzinie stosunków z organizacjami międzynarodowymi - w odniesieniu do członkostwa Polski w Radzie Europy i związanego z tym uznania jurysdykcji ETPC - obejmuje różnego rodzaju działania. Są to działania takie jak: a) podejmowanie decyzji o charakterze strategicznym, związanych z członkostwem w tej organizacji międzynarodowej; b) wdrażanie w systemie prawa krajowego i upowszechnianie standardów poszanowania wolności i praw jednostki określonych w EKPC; c) reprezentowanie państwa w postępowaniach przed ETPC; d) wykonywanie orzeczeń ETPC wydanych w sprawach przeciwko Polsce, polegające na realizacji środków indywidualnych i generalnych; e) koordynacja wykonywania orzeczeń ETPC na poziomie konstytucyjnych organów państwa oraz organów administracji rządowej i samorządowej.

\section{Podmioty rządowe odpowiedzialne za wykonywanie orzeczeń Europejskiego Trybunału Praw Człowieka}

Kompetencje w zakresie wykonywania orzeczeń Trybunału oraz koordynacja tego procesu zostały w ramach Rady Ministrów powierzone ministrowi spraw zagranicznych i podległemu mu resortowi. Realizacja przez ministra spraw zagranicznych zadań w zakresie wykonywania orzeczeń ETPC jest możliwa dzięki odpowiedniej strukturze organizacyjnej oraz współpracy z innymi resortami. W celu wykonania konkretnych orzeczeń ETPC Ministerstwo Spraw Zagranicznych współpracuje z resortami właściwymi przedmiotowo ze względu na przedmiot skargi indywidualnej skierowanej do ETPC. Współpraca ta ma służyć efektywności wykonywania orzeczeń ETPC w systemie prawa i praktyce organów krajowych ${ }^{16}$.

W Ministerstwie Spraw Zagranicznych wyodrębniono Departament do spraw Postępowań przed Międzynarodowymi Organami Ochrony Praw Człowieka. Celem jego działania jest reprezentacja interesów Rzeczypospolitej Polskiej w postępowaniach skargowych przed międzynarodowymi organami stojącymi na straży ochrony praw człowieka, w szczególności przed ETPC. Departament inicjuje także działania na rzecz dostosowania polskiego ustawodawstwa i praktyki sądowej do międzynarodowych standardów w dziedzinie ochrony praw człowieka.

16 I. Wrońska, Pozycja ustrojowa władzy wykonawczej w Polsce w aspekcie wykonywania wyroków Europejskiego Trybunału Praw Człowieka - wybrane zagadnienia, „Białostockie Studia Prawnicze" 2016, z. 20/B, s. 205-207. 
W 2003 r. na mocy zarządzenia ministra spraw zagranicznych ustanowiono Pełnomocnika Ministra Spraw Zagranicznych do spraw postępowań przed Europejskim Trybunałem Praw Człowieka ${ }^{17}$. Pełnomocnika wyznacza i odwołuje minister spraw zagranicznych $\mathrm{w}$ drodze decyzji ${ }^{18}$. Można wyodrębnić dwie sfery działania pełnomocnika. Po pierwsze, reprezentuje on Rzeczpospolitą Polską jako stronę $\mathrm{w}$ postępowaniu prowadzonym przed ETPC na zasadach określonych $\mathrm{w}$ regulaminie Trybunału ${ }^{19}$. Po drugie, pełnomocnik koordynuje współpracę rządu $z$ innymi organami lub podmiotami zaangażowanymi w wykonywanie orzeczeń Trybunału. W tym zakresie pełnomocnik wykonuje następujące zadania: a) przewodniczy międzyresortowemu Zespołowi do spraw Europejskiego Trybunału Praw Człowieka; b) przygotowuje plany działań oraz raporty z realizacji przez organy władzy publicznej działań służących wykonywaniu orzeczeń ETPC; c) opracowuje projekty rządowych informacji rocznych na temat wykonywania wyroków Trybunału; d) opiniuje rządowe projekty aktów prawnych pod względem zgodności ze standardami EKPC; e) koordynuje proces tłumaczenia na język polski orzeczeń ETPC oraz innych dokumentów Rady Europy i Trybunału dotyczących standardów ochrony praw człowieka ${ }^{20}$.

Pełnomocnik przy wykonywaniu powierzonych zadań jest obowiązany kierować się potrzebą ochrony interesów Rzeczypospolitej Polskiej oraz zapewnienia poszanowania prawa, w tym zobowiązań prawnomiędzynarodowych państwa w dziedzinie praw człowieka. Pełnomocnik ma obowiązek przedkładania ministrowi spraw zagranicznych półrocznych sprawozdań ze swej działalności, które po akceptacji przez ministra są przekazywane do wiadomości członkom Rady Ministrów. W sprawozdaniach pełnomocnik zamieszcza zwięzły opis stanu skarg wniesionych do ETPC przeciwko Polsce i toczących się postępowań oraz informację w przedmiocie realizacji przez państwo zobowiązań wynikających z orzeczeń Trybunału. Do sprawozdań mogą zostać dołączone propozycje zmian usta-

17 Zarządzenie nr 7 Ministra Spraw Zagranicznych z dnia 27 października 2003 r. w sprawie ustanowienia i zadań Pełnomocnika Ministra Spraw Zagranicznych do spraw postępowań przed Europejskim Trybunałem Praw Człowieka, Dz.Urz. MSZ z 2003 r., nr 4, poz. 53 ze zm.

18 W latach 1994-2003 tożsamą rolę pełnił Pełnomocnik do spraw reprezentowania Rzeczypospolitej Polskiej przed Europejskim Trybunałem Praw Człowieka Krzysztof Drzewicki. Od 2003 r. funkcję pełnomocnika pełnili kolejno: Jakub Wołąsiewicz (2003-2012) i Justyna Chrzanowska (2012-2018). Od dnia 16 października 2018 r. pełnomocnikiem jest Jan Sobczak. We wrześniu 2012 r. minister spraw zagranicznych wyznaczył również dwóch zastępców pełnomocnika oraz Pełnomocnika do spraw koordynacji wykonywania orzeczeń Europejskiego Trybunału Praw Człowieka.

19 Zob. https://echr.coe.int/Documents/Rules_Court_ENG.pdf (dostęp: 15.09.2018).

20 Zob. J. Chrzanowska, Rola Agenta Rządu w postępowaniach przed Europejskim Trybunatem Praw Człowieka, [w:] Reprezentacja Rzeczypospolitej Polskiej przed Europejskim Trybunałem Praw Człowieka - ponad dwie dekady doświadczeń Ministerstwa Spraw Zagranicznych. Konferencja zorganizowana przez Ministerstwo Spraw Zagranicznych w dniu 30 maja 2017 r. w Warszawie, Warszawa 2017, s. 27 i n. 
wodawczych w celu prawidłowego wykonywania zobowiązań państwa w zakresie ochrony praw człowieka oraz wynikające z orzecznictwa ETPC wnioski dotyczące działań krajowych organów administracji publicznej.

$\mathrm{W}$ ramach realizacji powierzonych zadań pełnomocnik współdziała $\mathrm{z}$ właściwymi komórkami organizacyjnymi ministerstw oraz innych jednostek organizacyjnych odpowiedzialnych za obsługę organów władzy publicznej. Współpraca jest zatem bardzo ważnym elementem realizacji przez organy władzy publicznej zobowiązań państwa wynikających z członkostwa w Radzie Europy i związanego z tym uznania jurysdykcji ETPC.

Z kolei w lipcu 2007 r. utworzono międzyresortowy Zespół do spraw Europejskiego Trybunału Praw Człowieka ${ }^{21}$ (dalej: Zespół), który koordynuje wykonywanie orzeczeń Trybunału. W ten sposób Polska zrealizowała zalecenie CM/REC(2008)2 dotyczące skutecznej zdolności krajowej do szybkiego wykonywania wyroków ETPC. Zespół został pomyślany jako organ opiniodawczo-doradczy Prezesa Rady Ministrów. W jego skład wchodzą: przewodniczy - Pełnomocnik Ministra Spraw Zagranicznych do spraw postępowań przed Europejskim Trybunałem Praw Człowieka, przedstawiciele poszczególnych resortów rządowych, eksperci wyznaczeni przez Prezesa Prokuratorii Generalnej Skarbu Państwa, szefa Kancelarii Prezesa Rady Ministrów oraz Pełnomocnika Rządu do spraw Równego Traktowania (członkowie) i sekretarz - osoba wyznaczona przez przewodniczącego Zespołu spośród pracowników komórki organizacyjnej Ministerstwa Spraw Zagranicznych odpowiedzialnej za reprezentację Polski przed międzynarodowymi organami ochrony praw człowieka.

Zadania Zespołu zostały szeroko określone przepisami zarządzenia nr 73 Prezesa Rady Ministrów, które również w tym zakresie ulegało zmianie od 2007 r. Do zadań Zespołu należą: a) wypracowywanie, na wniosek ministra właściwego do spraw zagranicznych lub przewodniczącego Zespołu, propozycji stanowisk dotyczących najważniejszych problemów wynikających ze skarg komunikowanych przez Europejski Trybunał Praw Człowieka, zwany dalej „Trybunałem”, oraz wydanych przez niego orzeczeń w sprawach przeciwko Polsce; b) wypracowywanie oraz przedstawianie Radzie Ministrów, na wniosek ministra właściwego do spraw zagranicznych lub przewodniczącego Zespołu, propozycji działań mających na celu zapobieganie naruszaniu przez Polskę Konwencji o ochronie praw człowieka i podstawowych wolności; c) monitorowanie wykonywania wyroków i decyzji Trybunału wobec Polski w oparciu o dokumenty i informacje dotyczące wykonywania wyroków i decyzji przedstawiane przez właściwych ministrów z własnej inicjatywy lub na wniosek ministra właściwego do spraw zagranicznych oraz analizowanie

21 Zarządzenie nr 73 Prezesa Rady Ministrów z dnia 19 lipca 2007 r. w sprawie utworzenia Zespołu do spraw Europejskiego Trybunału Praw Człowieka, https://bip.kprm.gov.pl/kpr/ bip-rady-ministrow/organy-pomocnicze/organy-pomocnicze-preze/159,Zespol-do-sprawEuropejskiego-Trybunalu-Praw-Czlowieka.html (dostęp: 15.09.2018). 
ewentualnych problemów związanych z ich wykonywaniem; d) przygotowywanie rocznych informacji na temat stanu wykonywania wyroków Trybunału, przedkładanych w terminie do dnia 31 marca roku następującego po roku stanowiącym okres sprawozdawczy, za pośrednictwem ministra właściwego do spraw zagranicznych, do przyjęcia Radzie Ministrów; e) opiniowanie, na wniosek ministra właściwego do spraw zagranicznych, innego właściwego ministra lub przewodniczącego Zespołu, projektów aktów prawnych budzących szczególne wątpliwości co do ich zgodności z Konwencją o ochronie praw człowieka i podstawowych wolności oraz z orzecznictwem Trybunału; f) omawianie najważniejszych problemów dotyczących orzecznictwa Trybunału wobec innych państw, a także ogólnych problemów dotyczących funkcjonowania Trybunału i ich implikacji dla Polski; g) analizowanie, na wniosek członków Zespołu, innych problemów związanych z problematyką ochrony praw człowieka.

Zespół obraduje na posiedzeniach in pleno oraz w ramach grup roboczych. Podczas posiedzeń omawiane i analizowane są problemy wynikające ze skarg komunikowanych rządowi i wyroków wydawanych przez Trybunał. Na forum Zespołu omawiane są również szczególnie znaczące problemy dotyczące zgodności projektowanych zmian ustawowych z Konwencją, z którymi mogą się wiązać istotne skutki dla prawa lub praktyki w Polsce. W trybie obiegowym Zespół uzgadnia plany działania rządu w zakresie wykonywania poszczególnych wyroków Trybunału.

Posiedzenia plenarne odbywają się co najmniej raz na kwartał. Są zwoływane przez przewodniczącego Zespołu z własnej inicjatywy, na wniosek sekretarza lub na wniosek co najmniej połowy członków Zespołu. Poza członkami Zespołu w posiedzeniach, z głosem doradczym, uczestniczą przedstawiciele innych instytucji i urzędów państwowych, w szczególności przedstawiciele Sejmu i Senatu Rzeczypospolitej Polskiej, Kancelarii Prezydenta Rzeczypospolitej Polskiej, Najwyższej Izby Kontroli, Rzecznika Praw Obywatelskich, Rzecznika Praw Dziecka, Rzecznika Praw Pacjenta, Trybunału Konstytucyjnego, Sądu Najwyższego, Naczelnego Sądu Administracyjnego, Krajowej Rady Sądownictwa, sądów powszechnych i administracyjnych, Prokuratora Generalnego, Komendanta Głównego Policji, Dyrektora Generalnego Służby Więziennej, Rady Legislacyjnej, Rządowego Centrum Legislacji, a także przedstawiciele innych właściwych organów administracji rządowej i samorządowej, zawodów prawniczych oraz organizacji pozarządowych zajmujących się problematyką ochrony praw człowieka.

Niezależnie od posiedzeń plenarnych członkowie Zespołu współpracują w ramach grup roboczych, gdzie omawiana jest strategia wykonywania konkretnych wyroków ETPC. W spotkaniach grup roboczych uczestniczą przedstawiciele tych resortów lub instytucji, które ze względu na swoją właściwość są zainteresowane wykonaniem danego wyroku ETPC.

Przewodniczący Zespołu jest obowiązany do przedstawiania Prezesowi Rady Ministrów kwartalnych sprawozdań z działalności Zespołu (do 10 dnia miesiąca następującego po zakończeniu okresu sprawozdawczego). W sprawozdaniach 
przewodniczący Zespołu może zwrócić uwagę na problemy dotyczące funkcjonowania Zespołu, w tym np. na brak wyznaczenia członków Zespołu przez ministrów kierujących działami administracji rządowej, Prezesa Prokuratorii Generalnej Skarbu Państwa, szefa Kancelarii Prezesa Rady Ministrów oraz Pełnomocnika Rządu do spraw Równego Traktowania lub niedopełnienie przez organy administracji rządowej oraz podległe im państwowe jednostki organizacyjne obowiązków wynikających z zarządzenia $\mathrm{nr} 73$.

\section{Działania rządu w zakresie wykonywania orzeczeń Europejskiego Trybunału Praw Człowieka}

W ramach wykonywania orzeczeń ETPC Rada Ministrów podejmuje różnego rodzaju działania, które opierają się - co już zostało zaznaczone - na współpracy resortów rządowych także z organami zewnętrznymi, w szczególności z Sejmem i Senatem ${ }^{22}$. Od $2013 \mathrm{r}$. Rada Ministrów zatwierdza roczne raporty z wykonywania wyroków Europejskiego Trybunału Praw Człowieka przez Polskę ${ }^{23}$, które sporządza Pełnomocnik Ministra Spraw Zagranicznych do spraw postępowań przed ETPC na podstawie materiałów przedłożonych przez poszczególne resorty i inne podmioty odpowiedzialne za wykonanie konkretnych orzeczeń. Raport zawiera dane statystyczne i zestawienia wyroków ETPC zapadłych w sprawach polskich w roku objętym sprawozdawczością oraz spraw pozostających w procedurze wykonywania przed Komitetem Ministrów Rady Europy. Zawiera on rów-

22 Członkowie Rady Ministrów m.in. uczestniczą w posiedzeniach sejmowej Komisji Sprawiedliwości i Praw Człowieka oraz senackiej Komisji Praw Człowieka, Praworządności i Petycji, podczas których rozpatrywane są np. roczne sprawozdania z prac rządu nad wykonaniem wyroków ETPC. W dniu 5 lutego 2014 r. na wspólnym posiedzeniu sejmowej Komisji Sprawiedliwości i Praw Człowieka oraz Komisji Spraw Zagranicznych powołano Podkomisję stałą do spraw wykonywania przez Polskę wyroków Europejskiego Trybunału Praw Człowieka. Miało to służyć m.in. wykonaniu Rezolucji Zgromadzenia Parlamentarnego Rady Europy: Resolution 1823 (2011), National parliaments: guarantors of human rights in Europe, http://assembly.coe. int/nw/xml/XRef/Xref-XML2HTML-en.asp?fileid=18011\&lang=en (dostęp: 15.09.2018). Do kompetencji podkomisji należało szczegółowe rozpatrywanie informacji Rady Ministrów na temat stanu wykonywania przez Polskę wyroków ETPC, monitorowanie wyroków Trybunału, które zostały wydane w sprawach przeciwko Polsce i przygotowanie projektów dezyderatów lub opinii Komisji Sprawiedliwości i Praw Człowieka oraz Komisji Spraw Zagranicznych w sprawie realizacji przez Radę Ministrów obowiązku wykonania przez Polskę wyroków ETPC. Pod koniec 2015 r. Podkomisja przestała jednak funkcjonować. Zob. m.in. A. Szklanna, Rola parlamentu krajowego w wykonywaniu wyroków Europejskiego Trybunału Praw Człowieka, [w:] Reprezentacja Rzeczypospolitej Polskiej..., s. 91 i n.

23 Pierwszy raport dotyczył roku 2012. 
nież opis wykonanych w danym roku orzeczeń, pełne teksty wszystkich planów działań i raportów z wykonania wyroków Trybunału przedłożonych przez rząd Rzeczypospolitej Polskiej do Rady Europy oraz teksty decyzji przyjętych w sprawach polskich przez Komitet Ministrów Rady Europy. W raporcie prezentowane są ponadto wybrane działania podejmowane na rzecz usprawnienia wykonywania wyroków ETPC i upowszechnienia orzecznictwa Trybunału (np. informacje o przetłumaczonych na język polski orzeczeniach Trybunału w sprawach przeciwko innym państwom, o zorganizowanych konferencjach, wizytach, konkursach itp.). Do raportu dołączany jest wykaz pożądanych w kontekście wykonywania wyroków Trybunału zmian w prawie i praktyce jego stosowania. Raport rozpatrywany jest na posiedzeniu senackiej Komisji Praw Człowieka, Praworządności i Petycji.

Dla uznania przez Komitet Ministrów Rady Europy, że Polska wykonała dany wyrok Trybunału zazwyczaj nie wystarczy zastosowanie tzw. środków indywidualnych. Z punktu widzenia standardów konwencyjnych, jeżeli źródłem naruszenia EKPC było obowiązujące prawo krajowe lub niezgodna ze standardami strasburskimi praktyka jego stosowania, konieczne jest podjęcie działań o charakterze generalnym. Rada Ministrów podejmuje w tym zakresie następujące typy działań: 1) wykonawcze sensu stricto (związane z wykonaniem konkretnego orzeczenia w sprawie przeciwko Polsce); 2) programowe (ustalenia co do działań służących wykonaniu orzeczeń); 3) legislacyjne (inicjowanie zmian w prawie, w szczególności inicjatywa ustawodawcza); 4) koordynujące (działalność Zespołu do spraw Europejskiego Trybunału Praw Człowieka); 5) kooperacyjne (współpraca $\mathrm{z}$ innymi organami państwa w celu wykonania orzeczeń); 6) propagujące standardy konwencyjne (tłumaczenia orzeczeń ETPC oraz ich publikowanie i upowszechnianie); 7) edukacyjne (upowszechnianie wiedzy na temat EKPC oraz orzecznictwa ETPC w ramach organizacji wykładów, konferencji i seminariów, np. Warszawskie Seminaria Praw Człowieka jako międzynarodowe forum wymiany doświadczeń kadry naukowej i praktyków związanych z działalnością ETPC); 8) sprawozdawcze (coroczny raport z wykonania orzeczeń Trybunału).

Spośród wymienionych wyżej form aktywności Rady Ministrów mających na celu wykonywanie orzeczeń ETPC warto zwrócić uwagę na dwa działania, których zainicjowanie i realizacja przynoszą zakładane rezultaty, co przekłada się na spadek liczby wnoszonych skarg oraz spraw polskich pozostających do wykonania w Sekcji Wykonywania Wyroków Sekretariatu Rady Europy. Pozwoliły one bowiem na wypracowanie swego rodzaju optymalnego modelu - formuły pozwalającej w sposób systematyczny i regularny badać zgodność przepisów i praktyki krajowej ze standardem strasburskim. Pierwsze ramy instytucjonalne w zakresie wykonywania wyroków strasburskich na poziomie krajowym zostały określone w Programie Działań Rządu w sprawie wykonywania wyroków Europejskiego Trybunału Praw Człowieka wobec Rzeczypospolitej Polskiej (dalej: Program Działań Rządu 
lub Program), który Rada Ministrów przyjęła 17 maja $2007 \mathrm{r}^{24} \mathrm{U}$ jego podstaw leży także dążenie do wzmocnienia poszanowania praw człowieka i zasady rządów prawa $\mathrm{w}$ Polsce. W celu zapewnienia kompleksowego i zgodnego ze standardami konwencyjnymi wykonywania orzeczeń strasburskich szczególnie istotne było powołanie zarządzeniem Prezesa Rady Ministrów z 19 lipca 2007 r. międzyresortowego Zespołu do spraw Europejskiego Trybunału Praw Człowieka. Z perspektywy ponad dziesięciu lat jego funkcjonowania można bowiem stwierdzić, że Zespół jest skutecznym mechanizmem koordynacji działań rządu w odniesieniu do naruszeń Konwencji przez Polskę, opartym na ścisłej współpracy międzyresortowej.

Program Działań Rządu zawierał propozycje działań mających na celu zwiększenie skuteczności wykonywania wyroków ETPC wobec Polski oraz zapobieganie na przyszłość stwierdzaniu przez Trybunał naruszenia postanowień Konwencji przez Polskę. Nie przesądzał on - właśnie z uwagi na programowy charakter zawartych w nim postanowień - konkretnych kierunków przyszłych rozwiązań, zwłaszcza prawnych, gdyż te kształtują się pod wpływem bieżącego orzecznictwa ETPC. Program stał się zatem podstawą systematycznego, opartego na współpracy, działania w celu poprawy prawa i praktyki krajowej w dziedzinie praw człowieka, w tym upowszechniania wiedzy na temat EKPC. W części II pt. „Polepszanie prawa i praktyki krajowej" wymienione zostały obszary, w których uznano za konieczne wprowadzenie zmian zgodnie $\mathrm{z}$ orzecznictwem ETPC, $\mathrm{w}$ tym m.in. przewlekłość postępowań sądowych i administracyjnych, rozszerzenie dostępu do sądu (np. zwiększenie gwarancji dla osób korzystających z bezpłatnej pomocy prawnej i wnioskujących o zwolnienie od opłat sądowych), zasady stosowania tymczasowego aresztowania i pozbawienia wolności, cenzura korespondencji z Trybunałem osób pozbawionych wolności, wzmocnienie skuteczności prawa rodziców do kontaktów z dzieckiem. Z kolei w części III sformułowano katalog działań edukacyjnych w społeczeństwie oraz omówiono sposoby upowszechniania standardów praw człowieka wśród organów, sądów i innych instytucji. Szczególnie istotna okazała się część V Programu oraz postanowienia dotyczące współpracy między ministrem spraw zagranicznych i pozostałymi ministrami w związku z problematyką skarg komunikowanych przez ETPC i wykonywaniem wydawanych przez niego wyroków. Wśród tych postanowień znalazł się także postulat utworzenia stałego międzyresortowego Zespołu przy Prezesie Rady Ministrów do spraw Europejskiego Trybunału Praw Człowieka.

Realizacja Programu w praktyce opierała się na kooperacji między resortami rządowymi, w której rolę koordynatora spełniał minister spraw zagranicznych. W dniu 3 października 2012 r. Rada Ministrów przyjęła w trybie obiegowym Spra-

24 Zob. https://www.msz.gov.pl/pl/polityka_zagraniczna/europejski_trybunal_praw_czlowieka/wykonywanie_orzeczen_europejskiego_trybunalu_praw_czlowieka/program_dzialan_ rzadu_ws_wykonywania_wyrokow_etpcz/program_dzialan_rzadu_w_sprawie_wykonywania_wyrokow_europejskiego_trybunalu_praw_czlowieka (dostęp: 15.09.2018). 
wozdanie $z$ realizacji Programu Działań Rządu w sprawie wykonywania wyroków Europejskiego Trybunału Praw Człowieka wobec Rzeczypospolitej Polskiej za okres 07.2008-07.2012 ${ }^{25}$. W ten sposób zamknięto realizację Programu, wskazując na potrzebę zmiany zarządzenia nr 73 Prezesa Rady Ministrów w celu uregulowania pracy Zespołu do spraw Europejskiego Trybunału Praw Człowieka w zakresie wykonywania wyroków ETPC w systemie polegającym na bieżącym wykonywaniu i sprawozdawczości w cyklach rocznych, bez konieczności opracowywania kolejnego programu działań rządu.

Co istotne, wypracowywanie stanowisk rządu polskiego w odniesieniu do komunikowanych skarg oraz wykonywanie wyroków ETPC opierało się i nadal opiera na ścisłej współpracy ministrów. W ramach owej współpracy minister spraw zagranicznych informuje pozostałych ministrów o skargach zakomunikowanych przez Trybunał, które mają szczególnie istotne znaczenie dla prawa i praktyki krajowej. Ministrowie z kolei przekazują ministrowi spraw zagranicznych informacje, dokumenty i wyjaśnienia niezbędne do przygotowania stanowiska rządu w przedmiocie skarg złożonych przeciwko Polsce. Szczególnie istotna - z uwagi na stosunkowo dużą liczbę skarg dotyczących funkcjonowania wymiaru sprawiedliwości (w tym zwłaszcza przewlekłości postępowań sądowych) - jest stała współpraca Ministerstwa Spraw Zagranicznych z Ministerstwem Sprawiedliwości, które opiniuje skargi zakomunikowane rządowi w tego typu sprawach. W procesie współpracy uczestniczą także instytucje spoza struktury rządowej, m.in. Prokuratura Generalna, Rzecznik Praw Obywatelskich, Naczelny Sąd Administracyjny oraz Kancelarie Sejmu i Senatu.

Niewątpliwie utworzenie w dniu 19 lipca 2007 r. Zespołu do spraw Europejskiego Trybunału Praw Człowieka znacząco przyczyniło się do urzeczywistnienia założeń Programu Działań Rządu, a po zakończeniu jego realizacji Zespół pozostał skutecznym mechanizmem współpracy międzyresortowej w zakresie wykonywania orzeczeń Trybunału przez Polskę. Zespół to realne forum wypracowywania propozycji działań rządu i uzgodnień w zakresie bieżących problemów związanych $\mathrm{z}$ wykonywaniem orzeczen ETPC $\mathrm{w}$ sprawach przeciwko Polsce oraz propozycji działań mających na celu zapobieganie naruszaniu Konwencji przez Polskę. Podstawowym zadaniem Zespołu jest zaś monitorowanie wykonywania wyroków i decyzji Trybunału wobec Polski.

Zadanie polegające in genere na monitorowaniu wykonywania wyroków ETPC Zespół realizuje na podstawie dokumentów i informacji przedstawianych przez ministrów właściwych ze względu na treść stwierdzonego przez Trybunał naruszenia $\mathrm{w}$ terminach określonych $\mathrm{w} ₫ 4 \mathrm{~b}$ zarządzenia $\mathrm{nr} 73$. Szczególna rola przypada przewodniczącemu Zespołu, który wspiera (przede wszystkim informuje członków Zespołu o orzeczeniach wydanych przez ETPC oraz o stanie wy-

25 Zob. https://www.msz.gov.pl/resource/c48983b6-56d3-446a-b9c5-dfb4869092c7:JCR (dostęp: 15.09.2018). 
konywania wyroków i decyzji Trybunału przez Polskę) i koordynuje realizację tego zadania. Ministrowie są obowiązani przedłożyć następujące dokumenty: a) tłumaczenie wyroku na język polski (chyba że w świetle klasyfikacji spraw stosowanej przez ETPC wyrok dotyczy spraw powtarzalnych i minister właściwy wraz z przewodniczącym Zespołu uznają za wystarczające przetłumaczenie wyroków Trybunału wydanych w innych podobnych sprawach); b) plan działań w sprawie wykonania ostatecznego wyroku Trybunału, zawierający informacje na temat wymaganych i planowanych środków indywidualnych i generalnych wraz z terminami ich wdrożenia; c) raport $\mathrm{z}$ działań podjętych w celu wykonania ostatecznego wyroku Trybunału, zawierający informacje na temat zrealizowanych środków indywidualnych i generalnych niezbędnych dla pełnego wykonania wyroku. Ministrowie przedkładają również informację na temat działań mających na celu upowszechnienie wyroku wśród podmiotów, których działania lub zaniechania dotyczy lub może dotyczyć stwierdzone przez Trybunał naruszenie Konwencji oraz zaktualizowane informacje na temat stanu wdrażania planu działań. W ramach monitorowania wykonywania decyzji ETPC Zespół opiera swoje działania na informacji ministra właściwego z uwagi na przedmiot decyzji o rozpowszechnieniu wśród organów, których działanie lub zaniechanie było przedmiotem skargi do Trybunału, informacji na temat treści ugody lub deklaracji jednostronnej wraz $\mathrm{z}$ informacją na temat mającego zastosowanie standardu konwencyjnego określonego w orzecznictwie Trybunału. Minister właściwy informuje także o działaniach planowanych lub podjętych przez podległe mu lub nadzorowane przez niego organy władzy publicznej, jeżeli takie działania są niezbędne w celu wykonania orzeczenia.

Do ważnych obowiązków Zespołu należy przygotowywanie rocznych informacji na temat stanu wykonywania wyroków ETPC. Informacje te, za pośrednictwem ministra właściwego do spraw zagranicznych, Zespół przedkłada Radzie Ministrów w terminie do dnia 31 marca roku następującego po roku stanowiącym okres sprawozdawczy. Podstawę wykonania tego zadania stanowią składane przez członków Zespołu jego przewodniczącemu - w terminie do dnia 31 stycznia roku następującego po roku stanowiącym okres sprawozdawczy - zbiorcze informacje na temat działań podjętych przez reprezentowany podmiot w celu wykonania wyroków Trybunału pozostających w ich właściwości, informacje na temat aktualnego stanu wykonania wyroków oraz ewentualnych przeszkód napotykanych w procesie wykonywania wyroków.

Utworzenie Zespołu do spraw Europejskiego Trybunału Praw Człowieka, co potwierdza praktyka, było bardzo dobrą decyzją polityczną Prezesa Rady Ministrów. Na efektywność prac Zespołu wpływa bez wątpienia aktywność samego przewodniczącego, który w imieniu ministra spraw zagranicznych pełni faktyczną rolę koordynatora uzgodnień międzyresortowych we współpracy z podmiotami zewnętrznymi. Dzięki pracom członków Zespołu w ciągu ostatnich lat znacznie wzrosła liczba orzeczeń ETPC uznanych przez Komitet Ministrów Rady Europy 
za wykonane przez Polskę, a tym samym doszło do zmniejszenia liczby orzeczeń Trybunału pozostających w procedurze wykonywania ${ }^{26}$.

Warto dodać, że dzięki inicjatywie Pełnomocnika Ministra Spraw Zagranicznych do spraw postępowań przed Europejskim Trybunałem Praw Człowieka w dniu 24 marca 2014 r. między Ministrem Sprawiedliwości, Ministrem Spraw Zagranicznych, Trybunałem Konstytucyjnym i Naczelnym Sądem Administracyjnym doszło do zawarcia porozumienia w sprawie tłumaczenia i udostępniania orzeczeń Europejskiego Trybunału Praw Człowieka w Strasburgu ${ }^{27}$, do którego w sierpniu 2015 r. przystąpił Prokurator Generalny ${ }^{28}$. Realizacja tego porozumienia służy wykonaniu Zalecenia $C M / \operatorname{Rec}(2002) 13 \mathrm{w}$ sprawie publikacji i rozpowszechniania w państwach członkowskich tekstu EKPC oraz orzecznictwa ETPC.

\section{Podsumowanie}

Rada Ministrów, realizując zadania określone w art. 146 ust. 1-2 i ust. 4 pkt 9 Konstytucji, odgrywa kluczową rolę w realizacji orzeczeń ETPC przez państwo. Działania Rady Ministrów w zakresie wykonywania orzeczeń ETPC wydanych w sprawach przeciwko Polsce, zarówno na poziomie środków indywidualnych, jak i generalnych, można ocenić pozytywnie ${ }^{29}$. Uzyskanie pozytywnych rezultatów jest możliwe dzięki temu, że realizacja orzeczeń Trybunału strasburskiego opiera się na skoordynowanej współpracy międzyresortowej. Celem efektywnego wykonywania orzeczeń ETPC rząd podejmuje także współpracę z innymi organami państwa (np. z parlamentem w zakresie koniecznych zmian w systemie prawa). Nie bez znaczenia jest również prowadzony przez parlament monitoring działań rządu, w szczególności na forum Komisji Praw Człowieka, Praworządności i Petycji Senatu Rzeczypospolitej Polskiej.

26 Zob. Ministerstwo Spraw Zagranicznych, Polska w systemie Europejskiej Konwencji Praw Człowieka. 25 lat Europejskiej Konwencji Praw Człowieka w Polsce, s. 15-16, https://www.msz.gov. $\mathrm{pl} /$ resource/64a2dc36-e2ea-4b3b-9c45-7360f27b826b:JCR (dostęp: 15.09.2018).

27 Zob. https://www.msz.gov.pl/resource/85eb2e14-e220-4874-834b-4cdb4a94c249:JCR (dostęp: 15.09.2018).

28 Zob. https://www.msz.gov.pl/resource/aaaf2c77-5683-453b-8dae-8e465e6c1790:JCR\%3E (dostęp: 15.09.2018).

29 Por. G. Mayer, Wykonywanie wyroków Europejskiego Trybunału Praw Człowieka w sprawach polskich - dokonania ostatnich 20 lat, [w:] Reprezentacja Rzeczypospolitej Polskiej..., s. 45 i n. Zob. także: Helsińska Fundacja Praw Człowieka, Wyrok w Strasburgu to nie koniec! Raport na temat wykonywania wyroków Europejskiego Trybunału Praw Człowieka, red. P. Kładoczny, K. Wiśniewska, Warszawa 2018, http://www.hfhr.pl/wp-content/uploads/2018/11/Wykonywanie-wyrok\%C3\%B3w-ETPC-2018-FIN.pdf (dostęp: 7.12.2018). 
Wpisana w procedurę wykonywania orzeczeń Trybunału strasburskiego współpraca międzyresortowa przynosi efekty dzięki działalności Zespołu do spraw Europejskiego Trybunału Praw Człowieka. Na efektywność prac zespołu przekłada się aktywna działalność przewodniczącego Zespołu, tj. Pełnomocnika Ministra Spraw Zagranicznych do spraw postępowań przed Europejskim Trybunałem Praw Człowieka, który jest także pełnomocnikiem procesowym rządu przed Trybunałem. Utworzenie Zespołu i realizacja powierzonych mu zadań pozwoliły na faktyczne skoordynowanie współpracy międzyresortowej, co można odczytywać w kategorii dobrej praktyki. W głównej mierze dzięki działaniom Zespołu Polska jest obecnie jednym z liderów pod względem zamkniętych postępowań strasburskich.

Na pozytywną ocenę prac rządu wpływają koordynowane przez Pełnomocnika i dyskutowane na forum Zespołu działania na rzecz koniecznych - z punktu widzenia orzecznictwa strasburskiego w sprawach przeciwko Polsce - zmian prawa i praktyki krajowej. Na szeroką skalę podejmowane są również inicjatywy rządu związane z upowszechnianiem standardów konwencyjnych i orzecznictwa Trybunału strasburskiego (np. tłumaczenia wyroków wydanych wobec innych państw), co jest kolejnym szczególnym przykładem dobrej praktyki.

Działania Rady Ministrów w celu wykonania orzeczeń ETPC i upowszechniania standardów konwencyjnych w prawie polskim oraz praktyce krajowej przekładają się na spadek zarówno liczby skarg kierowanych przeciwko Polsce, jak i liczby spraw pozostających w nadzorze Komitetu Ministrów Rady Europy. Z danych zawartych w corocznych rządowych raportach z wykonywania wyroków Europejskiego Trybunału Praw Człowieka przez Polskę oraz w rocznych raportach Komitetu Ministrów Rady Europy wydawanych w ramach nadzoru nad wykonywaniem orzeczeń Trybunału wynika, że liczba orzeczeń przeciwko Polsce pozostających w nadzorze Komitetu Ministrów na koniec 2017 r. spadła do 124 (102 wyroki i 23 decyzje zatwierdzające ugodę), podczas gdy na koniec $2016 \mathrm{r}$. w wykonywaniu pozostawały 223 orzeczenia, a jeszcze w 2011 r. - 924 orzeczenia $^{30}$. Zgodnie z ostatnim raportem Komitetu Ministrów Rady Europy pt. „Nadzór nad wykonywaniem wyroków i decyzji Europejskiego Trybunału Praw Człowieka za 2017 r., opublikowanym w dniu 4 kwietnia $2018 \mathrm{r}^{31}$, Komitet Ministrów uznał za wykonane 133 orzeczenia (w $2016 \mathrm{r}$. było to 170 orzeczeń, a w 2015 r. - 289 orzeczeń). W efekcie liczba spraw pozostających w wykonaniu jest najniższa od 10 lat, co może tylko potwierdzać skuteczność reprezentacji procesowej i działań podejmowanych przez polski rząd w celu wykonywania wyroków ETPC.

30 Raporty z wykonywania wyroków Europejskiego Trybunału Praw Człowieka przez Polskę za lata: 2012, 2013, 2014, 2015, 2016, 2017, https://www.msz.gov.pl/pl/polityka_zagraniczna/ europejski_trybunal_praw_czlowieka/wykonywanie_orzeczen_europejskiego_trybunalu_ praw_czlowieka/ (dostęp: 15.09.2018).

31 Supervision of the Execution of Judgments and Decisions of the European Court of Human Rights. $11^{\text {th }}$ Annual Report of the Committee of Ministers 2017, https://rm.coe.int/annual-report-2017/16807af92b (dostęp: 15.09.2018). 
Santrauka

\section{Ministrų Tarybos vaidmuo iggvendinant Europos Žmogaus Teisių Teismo sprendimus}

Lenkijos Ministrų Taryba vaidina pagrindinį vaidmenį igyvendinant Europos žmogaus teisių konvencijos 46 str. įtvirtintą pareiga vykdyti Europos Žmogaus Teisių Teismo sprendimus bylose prieš Lenkiją. Vadovaujantis Konstitucija, Ministrų Taryba yra labiausiai igaliota atlikti šią pareigą, kadangi vadovaujantis Konstitucijos 146 str, ji igyvendina užsienio politiką ir vykdo bendrą santykių vadybą su kitomis valstybėmis ir tarptautinemis organizacijomis. Tačiau ir kitos valstybès valdžios institucijos (Seimas, Senatas ir Respublikos Prezidentas) taip pat privalo laikytis Strasbūro teismo sprendimų. Siekiant veiksmingai igyvendinti Europos žmogaus teisių konvencijoje ittvirtintus standartus ir užtikrinti, kad valstybẻ laikytųsi Europos Žmogaus Teisių Teismo sprendimų, reikalingas šių institucijų bendradarbiavimas.

Ministrų Taryba yra institucija, atsakinga ne tik už EŽTT sprendimų vykdymą, bet ir už Konvencijos standartų igyvendinimą ir jų sklaidą. Šiuo tikslu ji vykdo įvairias veiklos rūšis. 2007 m. buvo priimta „Vyriausybès veiksmų programa dèl Europos Žmogaus Teisių Teismo sprendimų prieš Lenkijos Respubliką igyvendinimo", kurioje nustatyti sistemingi, bendradarbiavimą skatinantys veiksmai siekiant tobulinti teisę ir nacionalinę praktiką žmogaus teisių srityje, ịskaitant informavimą apie Konvenciją ir Strasbūro teismo praktiką. Nuo 2013 m. Ministrų Taryba kasmet rengia ataskaitą apie Europos Žmogaus Teisių Teismo sprendimų igyvendinimą, kuri turi būti patvirtinta Seime ir Senate.

EŽTT sprendimų vykdymas ir šio proceso koordinavimas buvo patikèti Užsienio reikalų ministrui ir jo pavaldžiai ministerijai. Siekiant užtikrinti EŽTT sprendimų efektyvų igyvendinimą teisès sistemoje ir nacionalinių valdžios institucijų praktikoje, Užsienio reikalų ministerija bendradarbiauja su objektyviai kompetentingomis (atsižvelgiant ị individualaus skundo objektą) institucijomis.

Europos Žmogaus Teisių Teismo sprendimų vykdymo koordinavimas priklauso 2007 m. ịsteigtai Europos žmogaus teisių teismo tarpžinybinei grupei. Tai Ministro Pirmininko patariamasis organas, ị kurị ieina atskirų ministerijų atstovai. Grupés darbui vadovauja Užsienio reikalų ministro įgaliotasis atstovas Europos žmogaus teisių teisme, kuris taip pat atstovauja valstybei EŽTT procesuose. 


\section{Literatura}

Bjorge E., Domestic Application of the ECHR: Courts as Faithful Trustees, Oxford 2015.

Brodziński W., Rozdziat 11: Rada Ministrów, [w:] D. Górecki (red.), Polskie prawo konstytucyjne, Warszawa 2015.

Chmielarz-Grochal A., Florjanowicz-Błachut P., Bezpośrednie stosowanie Konwencji o ochronie praw człowieka i podstawowych wolności przez sądy administracyjne, [w:] E. Wójcicka (red.), Sądowa kontrola administracji publicznej. Doświadczenia. Dylematy. Perspektywy, Częstochowa 2017.

Chrzanowska J., Rola Agenta Rządu w postępowaniach przed Europejskim Trybunałem Praw Człowieka, [w:] Reprezentacja Rzeczypospolitej Polskiej przed Europejskim Trybunałem Praw Człowieka - ponad dwie dekady doświadczeń Ministerstwa Spraw Zagranicznych. Konferencja zorganizowana przez Ministerstwo Spraw Zagranicznych w dniu 30 maja 2017 r. $w$ Warszawie, Warszawa 2017.

Dudek D., Komentarz do art. 146, [w:] M. Safjan, L. Bosek (red.), Konstytucja RP, t. II: Komentarz. Art. 87-243, Warszawa 2016.

Garlicki L., Masternak-Kubiak M., Władza sądownicza RP a stosowanie prawa międzynarodowego i prawa Unii Europejskiej, [w:] K. Wójtowicz (red.), Otwarcie Konstytucji RP na prawo międzynarodowe i procesy integracyjne, Warszawa 2006.

Garlicki L., Modelowy sposób stosowania Konwencji Europejskiej i orzecznictwa strasburskiego przez sady, [w:] IX Seminarium Warszawskie. Dysfunkcje polskiego prawa - jak poprawić system środków prawnych w Polsce?, Warszawa 2016.

Garlicki L., Obowiazywanie Europejskiej Konwencji Praw Człowieka w porzadku prawnym Rzeczypospolitej Polskiej, „Biuletyn Biura Informacji Rady Europy” 2003, nr 3.

Garlicki L., Rola sędziego krajowego w procesie wykonywania orzeczeń Europejskiego Trybunału Praw Człowieka, [w:] IX Seminarium Warszawskie. Dysfunkcje polskiego prawa - jak poprawić system środków prawnych w Polsce?, Warszawa 2016.

Keller H., Stone Sweet A., The Reception of the ECHR in National Legal Orders, [w:] H. Keller, A. Stone Sweet (red.), A Europe of Rights. The Impact of the ECHR on National Legal Systems, Oxford 2008.

Kropiwnicki R., System wykonywania wyroków Europejskiego Trybunału Praw Człowieka w Polsce, [w:] M. Jabłoński, S. Jarosz-Żukowska (red.), Aktualne wyzwania ochrony wolności i praw jednostki. Prace uczniów i wspótpracowników dedykowane Profesorowi Bogusławowi Banaszakowi, Wrocław 2014.

Mayer G., Wykonywanie wyroków Europejskiego Trybunału Praw Człowieka w sprawach polskich - dokonania ostatnich 20 lat, [w:] Reprezentacja Rzeczypospolitej Polskiej przed Europejskim Trybunałem Praw Człowieka - ponad dwie dekady doświadczeń Ministerstwa Spraw Zagranicznych. Konferencja zorganizowana przez Ministerstwo Spraw Zagranicznych $w$ dniu 30 maja 2017 r. $w$ Warszawie, Warszawa 2017. 
Mażewski L., Prowadzenie polityki zagranicznej w Rzeczypospolitej Polskiej, „Ruch Prawniczy, Ekonomiczny i Socjologiczny" 2009, nr 3.

Półtorak N., Rola sądów administracyjnych $w$ przestrzeganiu Konwencji o ochronie praw człowieka i podstawowych wolności, [w:] IX Seminarium Warszawskie. Dysfunkcje polskiego prawa - jak poprawić system środków prawnych w Polsce?, Warszawa 2016.

Szklanna A., Rola parlamentu krajowego w wykonywaniu wyroków Europejskiego TrybunaŁu Praw Człowieka, [w:] Reprezentacja Rzeczypospolitej Polskiej przed Europejskim Trybunałem Praw Człowieka - ponad dwie dekady doświadczeń Ministerstwa Spraw Zagranicznych. Konferencja zorganizowana przez Ministerstwo Spraw Zagranicznych w dniu 30 maja 2017 r. $w$ Warszawie, Warszawa 2017.

Wrońska I., Pozycja ustrojowa władzy wykonawczej w Polsce $w$ aspekcie wykonywania wyroków Europejskiego Trybunału Praw Człowieka - wybrane zagadnienia, „Białostockie Studia Prawnicze" 2016, z. 20/B.

\section{Akty prawne}

Deklaracja Konferencji Wysokiego Szczebla na temat przyszłości Europejskiego Trybunału Praw Człowieka z Interlaken, 19 lutego 2010 r., https://msz.gov.pl/pl/polityka_zagraniczna/europejski_trybunal_praw_czlowieka/zalecenia_km (dostęp: 15.09.2018).

Deklaracja Konferencji Wysokiego Szczebla na temat przyszłości Europejskiego Trybunału Praw Człowieka z Izmiru, 26-27 kwietnia 2011 r., https://msz.gov.pl/pl/polityka_zagraniczna/europejski_trybunal_praw_czlowieka/zalecenia_km (dostęp: 15.09.2018).

Deklaracja Konferencji Wysokiego Szczebla na temat przyszłości Europejskiego Trybunału Praw Człowieka z Brighton, 18-20 kwietnia 2012 r., https://msz.gov.pl/pl/polityka_ zagraniczna/europejski_trybunal_praw_czlowieka/zalecenia_km (dostęp: 15.09.2018).

Deklaracja Konferencji Wysokiego Szczebla w Brukseli na temat implementacji Konwencji o ochronie praw człowieka i podstawowych wolności - naszej wspólnej odpowiedzialności 27 marca 2015 r., https://msz.gov.pl/pl/polityka_zagraniczna/europejski_trybunal_praw_czlowieka/zalecenia_km (dostęp: 15.09.2018).

Deklaracja Konferencji Wysokiego Szczebla w Kopenhadze na temat dalszej reformy systemu Europejskiej Konwencji Praw Człowieka, 12-13 kwietnia 2018 r., https://msz.gov. pl/pl/polityka_zagraniczna/europejski_trybunal_praw_czlowieka/zalecenia_km (dostęp: 15.09.2018).

Konwencja o ochronie praw człowieka i podstawowych wolności, sporządzona w Rzymie dnia 4 listopada 1950 r., Dz.U. z 1993 r., nr 61, poz. 284 ze zm.

Resolution 1823 (2011), National Parliaments: guarantors of human rights in Europe, http:// assembly.coe.int/nw/xml/XRef/Xref-XML2HTML-en.asp?fileid=18011\&lang=en (dostęp: 15.09.2018).

Rules of Court, 1 August 2018, https://echr.coe.int/Documents/Rules_Court_ENG.pdf (dostęp: 15.09.2018).

Rules of the Committee of Ministers for the supervision of the execution of judgments and of the terms of friendly settlements (adopted by the Committee of Ministers on 10 May 
2006 at the $964^{\text {th }}$ meeting of the Ministers' Deputies and amended on 18 January 2017 at the $1275^{\text {th }}$ meeting of the Ministers' Deputies), https://search.coe.int/cm/Pages/result_details.aspx?ObjectId=09000016806dd2a5 (dostęp: 15.09.2018).

Zalecenie CM/Rec(2008)2 Komitetu Ministrów dla państw członkowskich dotyczące skutecznej zdolności krajowej do szybkiego wykonywania wyroków Europejskiego Trybunału Praw Człowieka, https://msz.gov.pl/pl/polityka_zagraniczna/europejski_trybunal_praw_czlowieka/zalecenia_km (dostęp: 15.09.2018).

Zalecenie CM/Rec(2010)3 Komitetu Ministrów dla państw członkowskich dotyczące skutecznych środków odwoławczych na przewlekłość postępowania, wraz z Podręcznikiem dobrych praktyk, https://msz.gov.pl/pl/polityka_zagraniczna/europejski_trybunal_praw_czlowieka/zalecenia_km (dostęp: 15.09.2018).

Zalecenie Rec(2000)2 Komitetu Ministrów dla państw członkowskich w sprawie ponownego rozpatrywania lub wznawiania pewnych spraw na poziomie krajowym na skutek wyroku Europejskiego Trybunału Praw Człowieka, https://msz.gov.pl/pl/polityka_zagraniczna/europejski_trybunal_praw_czlowieka/zalecenia_km (dostęp: 15.09.2018).

Zalecenie Rec(2002)13 Komitetu Ministrów dla państw członkowskich w sprawie publikacji i rozpowszechniania w państwach członkowskich tekstu Europejskiej Konwencji Praw Człowieka oraz orzecznictwa Europejskiego Trybunału Praw Człowieka, https:// msz.gov.pl/pl/polityka_zagraniczna/europejski_trybunal_praw_czlowieka/zalecenia_ km (dostęp: 15.09.2018).

Zalecenie Rec(2004)5 Komitetu Ministrów dla państw członkowskich w sprawie kontroli zgodności projektów aktów prawnych oraz istniejącego prawa i praktyki administracyjnej ze standardami wyrażonymi w Europejskiej Konwencji Praw Człowieka; https:// msz.gov.pl/pl/polityka_zagraniczna/europejski_trybunal_praw_czlowieka/zalecenia_ $\mathrm{km}$ (dostęp: 15.09.2018).

Zalecenie Rec(2004)6 Komitetu Ministrów dla państw członkowskich w sprawie ulepszenia krajowych środków prawnych (odwoławczych), https://msz.gov.pl/pl/polityka_zagraniczna/europejski_trybunal_praw_czlowieka/zalecenia_km (dostęp: 15.09.2018).

Zarządzenie nr 7 Ministra Spraw Zagranicznych z dnia 27 października 2003 r. w sprawie ustanowienia i zadań Pełnomocnika Ministra Spraw Zagranicznych do spraw postępowań przed Europejskim Trybunałem Praw Człowieka, Dz.Urz. MSZ z 2003 r., nr 4, poz. 53 ze zm.

Zarządzenie nr 73 Prezesa Rady Ministrów z dnia 19 lipca 2007 r. w sprawie utworzenia Zespołu do spraw Europejskiego Trybunału Praw Człowieka, https://bip.kprm.gov.pl/ kpr/bip-rady-ministrow/organy-pomocnicze/organy-pomocnicze-preze/159,Zespoldo-spraw-Europejskiego-Trybunalu-Praw-Czlowieka.html (dostęp: 15.09.2018).

\section{Pozostałe źródta}

Helsińska Fundacja Praw Człowieka, Wyrok w Strasburgu to nie koniec! Raport na temat wykonywania wyroków Europejskiego Trybunału Praw Człowieka, red. P. Kładoczny, K. Wiśniewska, Warszawa 2018, http://www.hfhr.pl/wp-content/uploads/2018/11/Wykonywanie-wyrok\%C3\%B3w-ETPC-2018-FIN.pdf (dostęp: 7.12.2018). 
Ministerstwo Spraw Zagranicznych, Polska w systemie Europejskiej Konwencji Praw Człowieka. 25 lat Europejskiej Konwencji Praw Człowieka w Polsce, https://www.msz.gov.pl/ resource/64a2dc36-e2ea-4b3b-9c45-7360f27b826b:JCR (dostęp: 15.09.2018).

Porozumienie w sprawie tłumaczenia i udostępniania orzeczeń Europejskiego Trybunału Praw Człowieka w Strasburgu zawarte w dniu 24 marca 2014 r. w Warszawie między Ministrem Sprawiedliwości, Ministrem Spraw Zagranicznych, Trybunałem Konstytucyjnym i Naczelnym Sądem Administracyjnym, https://www.msz.gov.pl/resource/85eb2e14-e220-4874-834b-4cdb4a94c249:JCR (dostęp: 15.09.2018).

Porozumienie w sprawie przystąpienia Prokuratora Generalnego do porozumienia w sprawie tłumaczenia i udostępniania orzeczeń Europejskiego Trybunału Praw Człowieka w Strasburgu z dnia 24 marca 2014 r. zawarte w dniu 31 sierpnia 2015 r. w Warszawie między Ministrem Sprawiedliwości, Ministrem Spraw Zagranicznych, Trybunałem Konstytucyjnym i Naczelnym Sądem Administracyjnym, Prokuratorem Generalnym, https://www.msz.gov.pl/resource/aaaf2c77-5683-453b-8dae-8e465e6c1790:JCR\%3E (dostęp: 15.09.2018).

Program Działań Rządu w sprawie wykonywania wyroków Europejskiego Trybunału Praw Człowieka wobec Rzeczypospolitej Polskiej, Warszawa, 17 maja 2007 r., https://www. msz.gov.pl/pl/polityka_zagraniczna/europejski_trybunal_praw_czlowieka/wykonywanie_orzeczen_europejskiego_trybunalu_praw_czlowieka/program_dzialan_rzadu_ ws_wykonywania_wyrokow_etpcz/program_dzialan_rzadu_w_sprawie_wykonywania_wyrokow_europejskiego_trybunalu_praw_czlowieka (dostęp: 15.09.2018).

Raporty z wykonywania wyroków Europejskiego Trybunału Praw Człowieka przez Polskę za poszczególne lata: 2012, 2013, 2014, 2015, 2016, 2017, https://www.msz.gov.pl/pl/ polityka_zagraniczna/europejski_trybunal_praw_czlowieka/wykonywanie_orzeczen_ europejskiego_trybunalu_praw_czlowieka/ (dostęp: 15.09.2018).

Sprawozdanie z realizacji Programu Działań Rządu w sprawie wykonywania wyroków Europejskiego Trybunału Praw Człowieka wobec Rzeczypospolitej Polskiej za okres 07.200807.2012, https://www.msz.gov.pl/resource/c48983b6-56d3-446a-b9c5-dfb4869092c7:JCR (dostęp: 15.09.2018).

Supervision of the Execution of Judgments and Decisions of the European Court of Human Rights. $11^{\text {th }}$ Annual Report of the Committee of Ministers 2017, https://rm.coe.int/annual-report-2017/16807af92b (dostęp: 15.09.2018). 